NBER WORKING PAPER SERIES

\title{
SOCIAL SECURITY CLAIMING DECISIONS: SURVEY EVIDENCE
}

John B. Shoven

Sita Nataraj Slavov

David A. Wise

Working Paper 23729

http://www.nber.org/papers/w23729

\author{
NATIONAL BUREAU OF ECONOMIC RESEARCH \\ 1050 Massachusetts Avenue \\ Cambridge, MA 02138 \\ August 2017
}

This research was funded by grant number G-2014-13657 from the Alfred P. Sloan Foundation to the National Bureau of Economic Research. We thank participants at the 2017 NBER/IFS workshop on Workshop on the Increase in Work at Older Ages. The views expressed herein are those of the authors and do not necessarily reflect the views of the National Bureau of Economic Research.

At least one co-author has disclosed a financial relationship of potential relevance for this research. Further information is available online at http://www.nber.org/papers/w23729.ack

NBER working papers are circulated for discussion and comment purposes. They have not been peer-reviewed or been subject to the review by the NBER Board of Directors that accompanies official NBER publications.

(C) 2017 by John B. Shoven, Sita Nataraj Slavov, and David A. Wise. All rights reserved. Short sections of text, not to exceed two paragraphs, may be quoted without explicit permission provided that full credit, including $\odot$ notice, is given to the source. 
Social Security Claiming Decisions: Survey Evidence

John B. Shoven, Sita Nataraj Slavov, and David A. Wise

NBER Working Paper No. 23729

August 2017

JEL No. D14,H55,J26

\begin{abstract}
$\underline{\text { ABSTRACT }}$ Security rules.

John B. Shoven

Department of Economics

579 Serra Mall at Galvez Street

Stanford, CA 94305-6015

and NBER

shoven@stanford.edu

Sita Nataraj Slavov

Schar School of Policy and Government

George Mason University

3351 Fairfax Drive, MS 3B1

Arlington, VA 22201

and NBER

sslavov@gmu.edu

David A. Wise

NBER

1050 Massachusetts Avenue

Cambridge, MA 02138

dwise@nber.org
\end{abstract}

While research shows that there are large gains in lifetime wealth from delaying claiming Social Security, most people claim at or before full retirement age. We fielded an original, nationally representative survey to gain insight into people's rationales for their Social Security claiming decisions, their satisfaction with their past claiming decisions, and how they financed any gap between retirement and claiming. Common rationales for claiming Social Security before full retirement age include stopping work, liquidity, poor health, and concerns about future benefit cuts due to policy changes. Claiming upon stopping work and claiming at full retirement age appear to be viewed as social norms. But while Social Security claiming is strongly associated with stopping work, the roughly quarter of the sample who have a gap of two or more years between retirement and claiming used employer-sponsored pensions and other saving to finance the delay. Individuals who claimed at full retirement age are more satisfied with their claiming decisions than individuals who claimed early or delayed. There is little evidence that claiming decisions and rationales for claiming are correlated with financial literacy or knowledge of Social 


\section{Introduction}

Social Security can be claimed at any age between 62 and 70, with individuals receiving larger monthly payments for later claims. These larger monthly payments are sometimes described as an actuarial adjustment intended to compensate for the fact that those who claim later will receive fewer monthly payments over their lifetime. However, a large literature documents that this adjustment is actuarially advantageous for important groups of people, such as primary earners (e.g., Meyer and Reichenstein 2010; Munnell and Soto 2005; Sass, Sun, and Webb 2007, 2013; Coile et al. 2002; Mahaney and Carlson 2007; Shoven and Slavov 2014a,b). Research focusing on more recent cohorts suggests that most individuals gain from delay due to historically low interest rates, changes in Social Security rules, and longer life expectancy (Meyer and Reicherstein 2010; Munnell and Soto 2005; Sass, Sun, and Webb, 2013; and Shoven and Slavov 2014a,b). But despite the large and growing gains from delay, most people claim at or before their full retirement age.

There are numerous potential explanations for this behavior. First, individuals may want to stop working and lack liquidity to finance the period between retirement and claiming. Goda et al. (2017) show that one-third to two-thirds of individuals have sufficient retirement wealth to finance a two-year gap between retirement and claiming. In addition, many individuals who claim Social Security before full retirement age simultaneously delay withdrawing money from their retirement accounts until they are forced to do so at age 701/2, a behavior that is inconsistent with the liquidity explanation. However, liquidity may be a rationale for some individuals who lack retirement wealth. ${ }^{1}$

Second, individuals may not believe they will live long enough to gain from delaying Social Security. Indeed, some studies have documented that individuals who have higher subjective or actual mortality risk tend to claim earlier (e.g., Goda et al. 2017; Hurd, Smith, and Zissimopoulos 2004; Glickman and

\footnotetext{
${ }^{1}$ Alternatively, individuals may view their retirement accounts and their Social Security wealth differently, being more willing to tap into the latter but not the former. Bequest motives may be one reason for this difference.
} 
Hermes 2015; Beauchamp and Wagner 2012; Waldron 2002). However, high mortality risk is not likely to explain why most people claim at or before fully retirement age, particularly given that even those with twice the average mortality risk stand to gain from delay (Shoven and Slavov 2014a).

Third, individuals may undervalue annuities. There is a large literature documenting the "annuity puzzle," a phenomenon where people fail to purchase annuities even though the insurance value they provide raises expected lifetime utility (see, e.g., Yaari 1965; Mitchell et al. 1999; Warner and Pleeter 2001). Delaying Social Security is equivalent to purchasing an annuity as it involves sacrificing current income in exchange for higher income for the remainder of life. And, unlike retail annuities, the Social Security annuity obtained from delay is available at a price that is better than actuarially fair. Thus, failure to delay Social Security may be a manifestation of the annuity puzzle. Standard economic models suggest that the gains from delay should be even larger when the insurance value of the Social Security annuity is considered (Sun and Webb 2009). In fact, Maurer et al. (2016) present survey evidence showing that people would be more willing to delay claiming if the gains from delay were paid as an actuarially fair lump sum rather than as an annuity. ${ }^{2}$

Fourth, it is possible that claiming at the designated full retirement age is a social norm because individuals view it as a reference point or a recommendation from the government. Behagel and Blau (2012) show that both claiming and retirement tend to cluster around the full retirement age as the full retirement age increases, even though benefits increase continuously with claiming age from age 62 through 70. In addition, claiming upon stopping work may be a social norm. Notably, Social Security

\footnotetext{
${ }^{2}$ In most instances of the annuity puzzle, it is unclear whether individuals are making mistakes when they fail to annuitize their wealth or whether economic models simply do not accurately capture individuals' preferences for annuitization. However, Bronshtein et al. (2017) document that many individuals simultaneously claim Social Security early while either purchasing a retail annuity or taking an annuity payout from a defined benefit pension. These individuals - in combination with their employers, who determine payout options for defined benefit pensions - are failing to take advantage of a potentially large arbitrage opportunity. The arbitrage opportunity involves forgoing the retail annuity or taking a lump sum from the defined benefit annuity and using the proceeds to delay Social Security. Consistent with this finding, Brown et al. (2016) present survey evidence showing large discrepancies between the prices at which people are willing to buy and sell annuities, and they attribute these discrepancies to limitations in financial decision-making ability.
} 
Administration publications often use the term "retirement" interchangeably with "claiming" even though retirement and claiming need not occur simultaneously, and even though the optimal approach to drawing down on retirement wealth may be to tap into other assets before claiming Social Security.

Fifth, individuals may be unaware of the rules surrounding Social Security delay. Liebman and Luttmer (2012) show that individuals accurately estimate the gains from delay between age 62 and full retirement age, but underestimate the gains from delay between full retirement age and age 70 . However, providing information about the gains from delay does not appear to change actual claiming behavior.

Finally, individuals may fear that if they do not claim early, their Social Security benefits may be cut when policy makers enact reform to restore solvency to the program. Regardless of whether this fear is realistic (all serious Social Security reform plans protect individuals close to retirement from benefit cuts), it may influence claiming decisions.

While there are many possible explanations for why individuals fail to take advantage of the gains from delaying Social Security, previous research has not found conclusive evidence to support any of them. We contribute to the exploration of these hypotheses by fielding an original, nationally representative survey to learn about people's rationales for their claiming decisions and their satisfaction with past claiming decisions. While asking individuals to rationalize their claiming decisions ex post is unlikely to provide definitive answers as to why people claim Social Security early, it can suggest possible hypotheses to explore in future research and possibly ways to modify theoretical models to better predict behavior. We also ask individuals who had a significant gap between retirement and claiming how they financed the delay period. ${ }^{3}$

\footnotetext{
${ }^{3}$ We previously fielded a similar survey with a group of individuals who receive retiree health benefits through the OneExchange health insurance marketplace operated by the benefits consulting firm Willis Towers Watson (Nyce et al. 2015). While that was not a nationally representative sample, it enabled us to test and refine the survey questions in this paper.
} 
Our survey suggests that individuals who claim early do so because they have stopped working, they lack liquidity, they are in poor health, or they fear Social Security benefits will be cut in the future. Most people are satisfied with their past claiming decisions, although those who claimed at full retirement age are more satisfied than those who claimed early or delayed. Most people report that they were aware of the gains from delay but were not influenced by them. Individuals who claimed at either age 62 or full retirement age are less likely to report being influenced by the gains from delay. We do not find a correlation between financial literacy or Social Security knowledge and claiming behavior or rationales for claiming. Overall, there is strong evidence that people view claiming at age 62 and claiming upon retirement as social norms. While claiming and retirement are strongly linked, the roughly quarter of the sample who have a gap of two or more years between retirement and claiming used employer-sponsored pensions and other saving to finance the delay.

\section{Data and Methods}

We fielded an original survey as part of the Understanding America Study (UAS). UAS is a nationally representative internet panel, and our survey was sent to the subset of 2,206 individuals aged 55 and older. Respondents were paid $\$ 3$ to complete the survey. The response rate was just over 80 percent, providing a sample of 1,783 . Of this sample, 991 individuals indicate currently receiving Social Security benefits, and 705 indicate that they expect to receive benefits in the future (the rest either did not expect to receive benefits or skipped the question). Among those who have claimed Social Security, we restrict the sample to individuals who report that they are receiving worker benefits (and received worker benefits at the time of their initial claim). We exclude individuals who report claiming worker benefits before age 62 (not plausible) and individuals who report that they are not currently working 
and have never worked in the past. ${ }^{4}$ Among those who have not claimed Social Security, we exclude those who expect to receive anything other than worker benefits and individuals who report that they expect to claim before age 62. We drop another handful of observations due to missing values for some of the variables used in the analysis ${ }^{5}$, resulting in a final sample of 558 individuals who have claimed and another 558 who have yet to claim.

Since UAS is an ongoing panel, we can merge in some relevant variables from previous waves of the survey. Specifically, we merge in data from surveys on financial literacy and knowledge about Social Security. The financial literacy survey includes questions about interest rates, inflation, and investment. A summary score, indicating the number of correct answers out of 20 , is also provided. The Social Security knowledge survey includes a series of 10 questions (one multiple choice and 9 true-false) on specific features of Social Security, including how benefits are calculated, who is eligible for benefits, and the gains from delaying claiming. We construct an index by summing the number of correct answers. ${ }^{6}$ Within the set of 10 questions, there is one true-false question that specifically refers to the gains from delay: "Social Security benefits are not affected by the age at which someone starts claiming." There is another true-false question that specifically refers to the link between claiming and retirement: "Social Security benefits have to be claimed as soon as someone retires." Because these questions are particularly relevant to the claiming decision, some of our analysis focuses on them individually. The Social Security knowledge survey also includes a measure of self-reported health on a 5-point scale. We construct an indicator for "good health" that takes on a value of 1 if the individual's health score is 3

\footnotetext{
${ }^{4}$ The gains from delay for secondary earners are quite modest because survivor benefits are paid based on the higher of the two benefits. Thus, the gains from delaying the secondary earner's benefit are paid as a first-to-die annuity, while the gains from delaying the primary earner's benefit are paid as a 100 percent joint and survivor annuity. The latter annuity is much more valuable than the former. We determine whether an individual is the secondary earner based on a question asking how the respondent's and spouse's earnings compare over their careers. Individuals who indicate that their earnings were lower than their spouses are dropped.

${ }^{5}$ We also drop a few individuals with a missing sampling weight (these are individuals who are not part of the nationally representative sample aged $55+$ ).

${ }^{6}$ The index is set to missing for individuals who did not answer any of the questions. However, a skipped question is treated as an incorrect answer for individuals who answered at least one of the questions.
} 
(good), 2 (very good), or 1 (excellent). The indicator takes on a value of 0 if self-assessed health is equal to 4 (fair) or 5 (poor).

We begin by examining claiming behavior and the relationship between retirement and claiming. Individuals who have claimed benefits are asked about their work status and the date they last worked if they are not currently working. Of the 558 individuals who have claimed benefits, 409 are not currently working. We define the date an individual last worked as his or her retirement date. We begin by examining the distribution of claiming ages for individuals who have claimed and the distribution of intended claiming ages for individuals who have not. We also examine the difference between claiming and retirement ages for the 409 individuals who have both claimed and retired. Individuals who report a gap of more than two years between retirement and claiming are asked how they financed the period between retirement and claiming. Options included savings, income from an employer-sponsored pension, a spouse's income, assistance from family and friends, a loan, or a mortgage. Individuals were asked to select all that applied, and they were also provided with an "other" option that allowed them to specify their own response. Of the 97 individuals with a gap of more than two years, 96 answered this question.

Individuals who have claimed are asked to indicate their agreement with the statement, "I am satisfied with my decision on when to start Social Security benefits," with responses ranging from strongly disagree to strongly agree. We examine the distribution of responses as well as how they are correlated with other observable factors, such as demographics, claiming age, and the gap between retirement and claiming. Of the 558 individuals who have claimed, 557 responded to this question. Individuals who claimed before their full retirement age are asked their rationale for claiming early. Of the 445 individuals who claimed before full retirement age, we have valid responses on this question 
for 444 of them. ${ }^{7}$ Those who claimed within 6 months of full retirement age are asked their rationale for claiming at (or around) full retirement age. Of the 67 people who claimed within 6 months of full retirement age, we have valid responses for 64 of them. ${ }^{8}$ Those who claimed more than 6 months after full retirement age are asked their rationale for delaying. We have valid responses for all 46 individuals who claimed more than 6 months after full retirement age. Among individuals who have not yet claimed, we identify those who have reached age 62 and ask them their rationale for not having claimed yet. We have valid responses for all 125 individuals who have reached age 62 but not claimed yet. For these questions, respondents are provided with a list of possible reasons and asked to select all that apply. In addition, there is an "other" option that allows a free form response. The order of the reasons (except for "other," which always appears last) are randomized across individuals. We tabulate these reasons and examine how they are correlated with demographics as well as satisfaction with claiming decision.

Finally, individuals who have claimed and were born in 1943 or later are asked about their awareness of the rules surrounding delay. For individuals born in 1943 or later, benefits increase by 8 percent of the benefit available at full retirement age for each year of delay through age 70. (Previous cohorts received less generous adjustments.) Prior to age full retirement age, benefits increase by around 7-8 percent per year with delay, though the exact percentage varies with age. In addition, benefits for surviving spouses are based on the higher of the two individual benefits. This rule generates a large portion of the gains from delay for primary earners, who can pass on a higher benefit to their

\footnotetext{
${ }^{7}$ One individual reports a year of 1910 and a claiming age of 65 in our survey. Since full retirement age for the 1910 birth cohort is 65, this respondent was treated as having claimed at full retirement age and not asked why she claimed before full retirement age. However, we suspect that the reported year of birth is incorrect, as it is inconsistent with the respondent's previously recorded year of birth in the UAS (1939). Full retirement age for the 1939 birth cohort is 65 years and 4 months. Thus, the respondent claimed before full retirement age but was not asked why.

${ }^{8}$ Due to a glitch in the survey, three individuals who claimed at full retirement age were inadvertently asked why they claimed before full retirement age. Thus, these three individuals do not have valid responses to this question.
} 
widows (see, e.g., Sass, Sun, and Webb 2013). We ask individuals whether they were aware of these rules, and if so, to what extent they influenced their claiming decisions. We tabulate the responses and examine how they are correlated with observables, including demographics and claiming decisions. There are 403 individuals who have claimed and were born in 1943 or later; of these individuals, 183 are married primary earners and would therefore be affected by the survivor benefit provision.

Sampling weights, called post-stratification weights, are included with the UAS survey results to make the sample representative of the population. We utilize these weights throughout our analysis.

\section{Results}

Table 1 provides summary statistics for the two main samples of primary earners used in this analysis. The first set of columns is based on the 558 individuals who have claimed, the middle set of columns is based on the 558 individuals who have not yet claimed, and last set of columns combines both samples. Not surprisingly, those who have already claimed tend to be older than those who have not, and they are also less likely to be working. Most people have had an IRA or 401(k). A slight majority are male, which may be because we have restricted the sample to individuals claiming worker benefits, and women are more likely than men to claim spousal or survivor benefits. Among those who have claimed, the mean retirement age is almost 63 , and the average difference between claiming age and retirement age is less than a month. However, 22 percent of the sample reports claiming more than two years after retiring.

Figure 1 shows the distribution of claiming ages for individuals who have claimed (a), the distribution of intended claiming ages for individuals who have not yet claimed (b), and the combined distribution of actual and intended claiming ages for all individuals regardless of whether they have claimed (c). In each diagram, vertical lines indicate ages 65 and 66; full retirement age for all individuals lies between these two ages. Not surprisingly, claiming ages for individuals who have already claimed 
tend to be lower than claiming ages for individuals who have not yet claimed, as the latter group is more likely to include those delaying beyond age 62 . The overall claiming age distribution (c) is consistent with previous research on claiming behavior. Specifically, most individuals claim at or before full retirement age, with spikes in claiming at both age 62 and full retirement age. Another small group waits (or intends to wait) until age 70 .

Figure 2 shows the distribution of the difference between claiming and retirement ages for individuals who have claimed and stopped working. The figure is restricted to individuals whose difference between claiming and retirement is less than or equal to 100 months in absolute value. The vertical lines indicate differences of -2 and +2 years between claiming and stopping work. Almost a quarter of the sample has a difference of zero months between claiming and retirement, and around half claim within \pm 2 years of retirement.

Table 2 presents regressions showing the relationship between actual and intended claiming ages and demographic characteristics. The first column is based on those who have already claimed, the second is based on those who have yet to claim, and the third is based on the combined sample. The third column includes an indicator for whether the individual has claimed to take into account the difference in mean claiming age for the two sub-samples. The results suggest that those who are primary earners, more educated, or have had an IRA/401(k) are more likely to delay claiming, with each of these factors delaying claiming by anywhere between 6 and 11 months. Older individuals tend to report higher claiming ages. We find no statistically significant relationship between claiming and the financial literacy score, Social Security knowledge score, or scores on the two Social Security questions most closely related to claiming.

Table 3 shows how financial literacy and Social Security knowledge scores are correlated with other observable characteristics. It suggests that older people generally know more about Social Security in general; they are also less likely to link claiming and retirement. Individuals who have ever had a 401(k) 
or IRA tend to have higher financial literacy and Social Security knowledge scores, and are less likely to link claiming and retirement. Married people are less likely to link claiming and retirement, and men are more likely to have higher financial literacy scores. Nonwhites tend to have lower financial literacy and Social Security knowledge scores. We find no evidence of a correlation between health and financial literacy or Social Security knowledge.

Table 4 presents results from estimating multinomial logit models to predict whether retirement occurs before, at, or after claiming age. The table presents marginal effects for each of the three outcomes, alternately including the financial literacy and Social Security knowledge scores or indicators for whether the individual answered the two claiming-related Social Security knowledge questions correctly. The results suggest that, compared to individuals who claim at 62 (the omitted category), those who claim either at full retirement age or between 62 and full retirement age are less likely to claim after retirement. This difference is likely because many of those who claim at 62 retired before 62 and claim as soon as they are able; that is, they may have wished to claim upon retirement but were constrained by the early eligibility age. There is no statistically significant difference between those who claim after full retirement age and those who claim at 62 . Table 5 shows that among individuals whose claim occurred more than two years after retirement, the majority relied on employer-sponsored pensions to finance the gap. A significant number drew down on retirement savings or relied on a spouse's income. Very few took out loans or received help from family and friends.

Table 6 tabulates individuals' satisfaction with their past claiming decisions. Almost 80 percent of people either agree or strongly agree that they are satisfied with their claiming decision. Table 7 reports results from regressing satisfaction (on a scale of $1-5$, with 1 representing strongly disagree and 5 representing strongly agree) on demographics, indicators for claiming age, and an indicator for a greater than two-year gap between claiming and retirement. It shows no significant relationships between demographics or financial/Social Security knowledge and satisfaction with claiming decisions (other than 
the fact that males are more likely to be satisfied with their claiming decisions). However, individuals who claimed at full retirement age are more satisfied with their claiming decision than individuals who claimed at 62 . In addition, individuals who claiming more than two years after retirement tend to be more satisfied than individuals who did not.

Table 8 tabulates the reasons individuals provide for their claiming decisions. The top panel shows that among those who claimed before full retirement age, the largest number did so because they had stopped working. Around 21 percent report that they "needed the money," indicating that liquidity may be an issue for a substantial number of people. Other common reasons include poor health (around 14 percent) and fear of benefit cuts (another 14 percent). Around 9 percent also indicate that they hoped to invest the money and end up ahead. About 5-7 percent claimed early based on advice from friends/family or a financial adviser. A very small percentage report being encouraged to claim early by an employee of the Social Security Administration. Some individuals may be induced to claim early because of a rule preventing the spouse of an individual who has not yet reached full retirement age from claiming a spousal benefit unless the individual has also claimed his or her retirement benefit. However, very few people indicate that this rule constrained their claiming choice. ${ }^{9}$ A large fraction of those who claimed early report "other" reasons. Many of the text responses for this question indicate stopping work (e.g., they refer to becoming disabled, being tired of working, or being laid off). Some individuals state that they did not fully understand the gains from delay. Others responses suggest that some individuals who claimed at age 65 mistakenly believed it to be their full retirement age.

The second panel of Table 8 shows that individuals who claimed between full retirement age and 6 months post full retirement age are most likely to indicate that it "seemed natural" to claim at full

\footnotetext{
${ }^{9}$ Prior to April 2016, individuals who had reached full retirement age could "file and suspend" their benefit, allowing their spouse to claim a benefit on their record while continuing to let their own benefit grow through delay. Individuals who reached full retirement age before April 2016 could exercise the file and suspend option and therefore only faced this constraint before full retirement age. However, those reaching full retirement age after April 2016 faced a similar constraint even after full retirement age.
} 
retirement age. Other common reasons include stopping work or wanting to avoid a "reduced" benefit. Compared to the early claimers, those who claimed at full retirement age are more likely to report being advised to do so by a financial adviser, friends or family, or a Social Security Administration employee. They are also more likely to report wanting to invest the money. However, they are less likely to cite health as a motivation for not delaying further, and a similar fraction reports fearing future benefit cuts. Prior to full retirement age, people who have claimed and continue to work are subject to an earnings test, which effectively forces those who earn more than a certain amount to delay a portion of benefits (and receive the actuarial adjustment for delay). Considering the generous actuarial adjustment for delay, application of the earnings test likely increases the expected present value of benefits for most people. However, prior research suggests that the earnings test is poorly understood, and that many people react to it as if it were a tax on earnings (see, e.g., Friedburg 2000; Haider and Loughran 2008; Gustman and Steinmeier 2007; Song and Manchester 2007). Our survey suggests that only around 8 percent of those who claimed at full retirement age viewed the earnings test as a constraint on their claiming decision.

The next panel of Table 8 tabulates the reasons for delaying beyond full retirement age. It is based on the sample of respondents who have claimed and did so more than 6 months after full retirement age. The final panel tabulates the reasons provided for not having claimed yet. It is based on the sample of respondents who have not claimed yet but have reached age 62 . Both panels indicate that continued work is a major reason for delay. Taking advantage of the gains from delay is also cited by more than 30 percent of both samples. Between 17 and 20 percent of both samples also cite good health. Among those who have claimed but did so more than 6 months after full retirement age, not needing the money is also a common response. People in this group are less likely than full retirement age claimers to cite advice from a financial adviser, friends or family, or a Social Security Administration employee. 
Most of the rationales for early claiming are uncorrelated with demographic characteristics and the gap between claiming and retirement. ${ }^{10}$ However, more highly educated and healthier individuals are less likely to cite poor health as a rationale; individuals with an IRA or 401(k) are more likely to cite advice from a financial professional; and men are less likely to cite advice from a financial professional or friends/family, or the retirement of a spouse. Not surprisingly, married people are more likely to cite the retirement of a spouse as a motivation for claiming early. Financial and Social Security literacy are mostly uncorrelated with rationales for early claiming, though those who believe that benefits are unaffected by start age are more likely to cite poor health as a reason for claiming early and those with greater Social Security knowledge are more likely to report claiming early because a spouse had stopped working.

Table 9 investigates the relationship between satisfaction with claiming decision (on a scale of 1-5, with 1 being strongly disagree and 5 being strongly agree) and the rationale behind claiming Social Security before full retirement age. Those who report claiming early due to poor health or liquidity report lower satisfaction with their claiming decisions; these are individuals who may have wished to delay but felt constrained to claim early. Those who were advised to claim early tend to report greater satisfaction. Those who claimed at full retirement age to avoid a "reduced" benefit or invest the money, or because they were advised to do so by the Social Security Administration, report greater satisfaction. Those who report having enough saved to take them through full retirement age but no further report lower satisfaction. Finally, those who delayed beyond full retirement age based because of a stillworking spouse report lower satisfaction.

Table 10 indicates that most people born in 1943 or later are aware of the rules surrounding delay for their cohort. However, this awareness generally did not influence their claiming decisions. The top

\footnotetext{
${ }^{10}$ Regression results not reported but are available upon request. There are even fewer correlations between the rationale for claiming at or beyond full retirement age and demographics. We hesitate to interpret these because there are very few statistically significant relationships and much smaller sample sizes.
} 
panel of Table 10 is based on the sample of individuals who have claimed and were born in 1943 and

later; the bottom panel is based on the subset of married primary earners (to whom the survivor benefit rule applies). Table 11 examines how awareness of the rules is correlated with other observable characteristics. It is based on multinomial logit regressions in which the dependent variable indicates whether the respondent was not aware of the rule, was aware but not influenced by the rule, was aware and somewhat influenced by the rule, or was aware and greatly influenced by the rule. The coefficients reported in the table are marginal effects. Two alternative specifications are used to predict the outcomes, one utilizing the summary financial literacy and Social Security knowledge scores and another using scores on the two Social Security questions related to claiming. The results suggest that individuals who delayed to full retirement age or beyond are more likely to report that the rules influenced their claiming decision compared to those who claimed before full retirement age. Primary earners and those in good health are more likely to be influenced by the 8 percent annual growth in benefits for delayers. There is some evidence that those with more education are also more likely to be aware and influenced by the rules as well.

\section{Discussion and Conclusions}

Our survey is intended to provide a preliminary overview of the rationales that people give for their Social Security claiming decisions. It is not intended to provide a definitive answer to the question of why people claim early when delay appears to be in their financial interest. Nonetheless, several interesting findings emerge from our results and can suggest directions for future research.

Our survey suggests that common rationales for claiming Social Security before full retirement age include stopping work, liquidity, poor health, and concerns about future benefit cuts due to policy changes. Common rationales for delay include continued work and a desire to take advantage of the 
gains from delay. Most people are satisfied with their claiming decisions and report that while they understand the rules surrounding delay, these rules did not influence their claiming decisions.

One key finding is that people appear to view claiming at full retirement age as a social norm. Those who claimed at full retirement age are highly likely to indicate that it seemed "natural" to do so, and that they wanted to avoid a "reduced" benefit (even though claiming at full retirement age also results in a reduced benefit relative to claiming at age 70). These responses are consistent with research by Behagel and Blau (2012) showing that both claiming and retirement ages tend to cluster around the full retirement age even when that age is changed by policy. Social norms may also explain why those who claim at full retirement age report greater satisfaction with their claiming decision than those who claimed at other ages, as well as why those who claimed at full retirement age are more likely to report being encouraged to do so by others (such as financial professionals, family or friends, or employees at the Social Security Administration). People who claimed at either age 62 or full retirement age appear to be less influenced by the rules surrounding delay than those who claim at other ages. This finding further suggests that claims at age 62 and full retirement age - compared to claims at other ages - may reflect social norms rather than calculations of lifetime wealth.

Another strong social norm appears to be claiming upon retirement, even though the retirement and claiming decisions can in theory be made independently. A large fraction of people claim very close to retirement and indicate that their claiming decision is strongly linked to their labor supply decision. While liquidity constraints may certainly induce individuals to claim upon retirement, previous research has shown that around two thirds of people have sufficient assets to delay Social Security for at least two years even if they have stopped working. And the survey evidence presented here suggests that those with retirement savings accounts are not less likely to cite labor force status as a rationale for their claiming decision. Thus, the link between retirement and claiming seems to go beyond concerns about liquidity. While Social Security claiming is strongly associated with stopping work, the roughly 
quarter of the sample who have a gap of two or more years between retirement and claiming used employer-sponsored pensions and other saving to finance the delay.

\section{References}

Beauchamp, Andrew and Mathis Wagner. 2012. "Dying to Retire: Adverse Selection and Welfare in Social Security." Unpublished manuscript.

Behaghel, Luc and David M. Blau. 2012. “Framing Social Security Reform: Behavioral Responses to Changes in the Full Retirement Age." American Economic Journal: Economic Policy 4(4): 41-67

Coile, Courtney, Peter Diamond, Jonathan Gruber and Alain Jousten. 2002. "Delays In Claiming Social Security Benefits." Journal of Public Economics 84(3): 357-385.

Friedburg, Leora. 2000. "The Labor Supply Effect of the Social Security Earnings Test," Review of Economics and Statistics 82(1): 48-63

Glickman, Mark M. and Sharon Hermes. 2015. "Why Retirees Claim Social Security at 62 and How It Affects Their Retirement Income: Evidence from the Health and Retirement Study." The Journal of Retirement 2(3): 25-39.

Goda, Gopi, Shanthi Ramnath, John B. Shoven, and Sita Nataraj Slavov. 2017. "The Financial Feasibility of Delaying Social Security: Evidence from Administrative Tax Data." Journal of Pension Economics and Finance, forthcoming.

Gustman, Alan L. and Thomas L. Steinmeier. 2007. “Projecting Behavioral Responses to the Next Generation of Retirement Policies." Working Paper no. Cambridge: National Bureau of Economic Research

Haider, Steven J. and David S. Loughran. 2008. "The Effect of the Social Security Earnings Test on Male Labor Supply: New Evidence from Survey and Administrative Data." Journal of Human Resources 153(1): 57-87. 
Hurd, Michael D., James P. Smith and Julie M. Zissimopoulos. 2004. "The Effects of Subjective Survival on Retirement and Social Security Claiming." Journal of Applied Econometrics 19(6): 761-775. Leibman, Jeffrey B. and Erzo F. P. Luttmer (2015), “Would People Behave Differently if They Better Understood Social Security? Evidence from a Field Experiment," American Economic Journal: Economic Policy 7(1): 275-299.

Mahaney, James I. and Peter C. Carlson. 2007. "Rethinking Social Security Claiming in a 401(k) World." Working Paper 2007-18. Philadelphia: Pension Research Council.

Maurer Raimond, Olivia S. Mitchell, Ralph Rogalla, and Tatjana Schimetschek. 2016. Journal of Risk and Insurance, forthcoming.

Mitchell, Olivia S., James M. Poterba, Mark J. Warshawsky, and Jeffrey R. Brown. 1999. “New Evidence on the Money's Worth of Individual Annuities." American Economic Review 89(5): 1299-1318. Meyer, William and William Reichenstein. 2010. "Social Security: When to Start Benefits and How to Minimize Longevity Risk." Journal of Financial Planning 23(3): 49-59.

Munnell, Alicia H. and Mauricio Soto. 2005. "Why Do Women Claim Social Security Benefits So Early?" Issue Brief 35, Center for Retirement Research. Chestnut Hill: Boston College.

Nyce, Steven, Sylvester Schieber, John Shoven, Sita Slavov, and David Wise. 2015.“Social Security and Defined Benefit Pension Payout Choices: Evidence from a Survey of Retirees." Unpublished manuscript.

Sass, Steven A., Wei Sun, and Anthony Webb. 2007. "Why Do Men Claim Social Security So Early: Ignorance or Caddishness?" Working Paper 2007-17, Center for Retirement Research. Chestnut Hill: Boston College.

Sass, Steven A., Wei Sun, and Anthony Webb. 2013. "Social Security Claiming Decision of Married Men and Widow Poverty." Economics Letters 119(1): 20-23. 
Shoven, John, and Sita Slavov. 2014a. "Does It Pay to Delay Social Security?" Journal of Pension Economics and Finance 13(2): 121-144.

Shoven, John, and Sita Slavov. 2014b. "Recent Changes in the Gains from Delaying Social Security." Journal of Financial Planning 27(3): 32-41.

Song, Jae and Joyce Manchester. 2000. "New Evidence on Earnings and Benefit Claims following Changes in the Retirement Earnings Test in 2000." Journal of Public Economics 91(3-4): 669700.

Sun, Wei and Anthony Webb. 2009. "How Much Do Households Really Lose by Claiming Social Security at Age 62?" Unpublished Manuscript

Waldron, Hilary. 2002. "Do Early Retirees Die Early? Evidence from Three Independent Data Sets."

Working Paper no. 97. Washington DC: Social Security Administration Office of Research, Evaluation, and Statistics

Warner, John T. and Saul Pleeter. 2001. "The Personal Discount Rate: Evidence from Military Downsizing Programs." American Economic Review, 91(1): 33-53.

Yaari, Menahem E. 1965. "Uncertain Lifetime, Life Insurance, and the Theory of the Consumer." Review of Economic Studies 32(2): 137-150. 
Figure 1: Distribution of Actual and Intended Claiming Ages

(a) Singles and primary earners who have claimed $(n=558)$

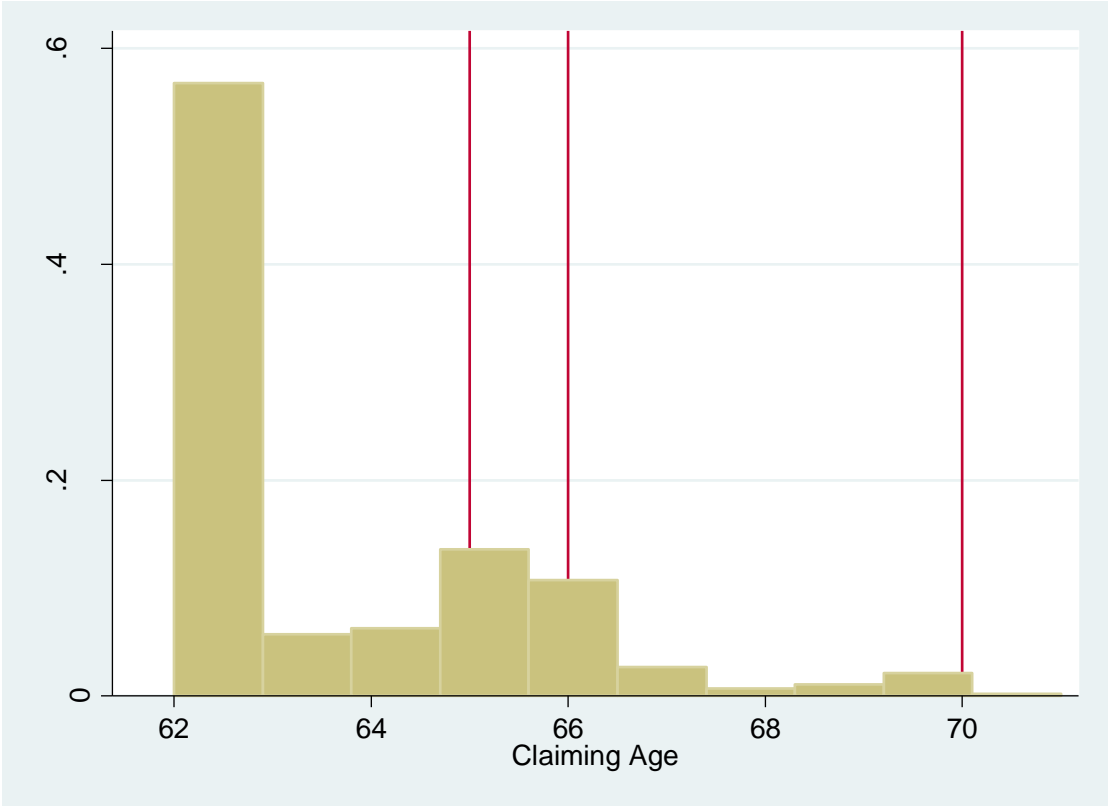

(b) Singles and primary earners who have not claimed $(n=558)$

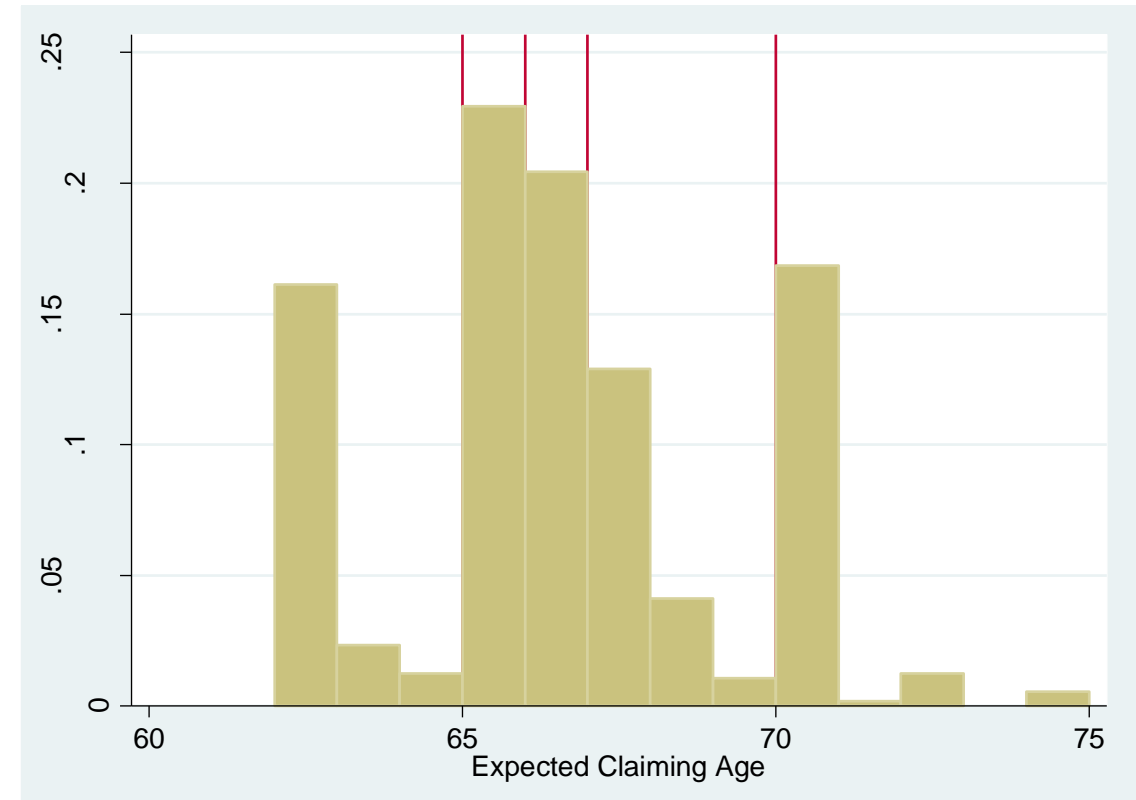


Figure 1 (continued)

(c) Full sample $(n=1,116)$

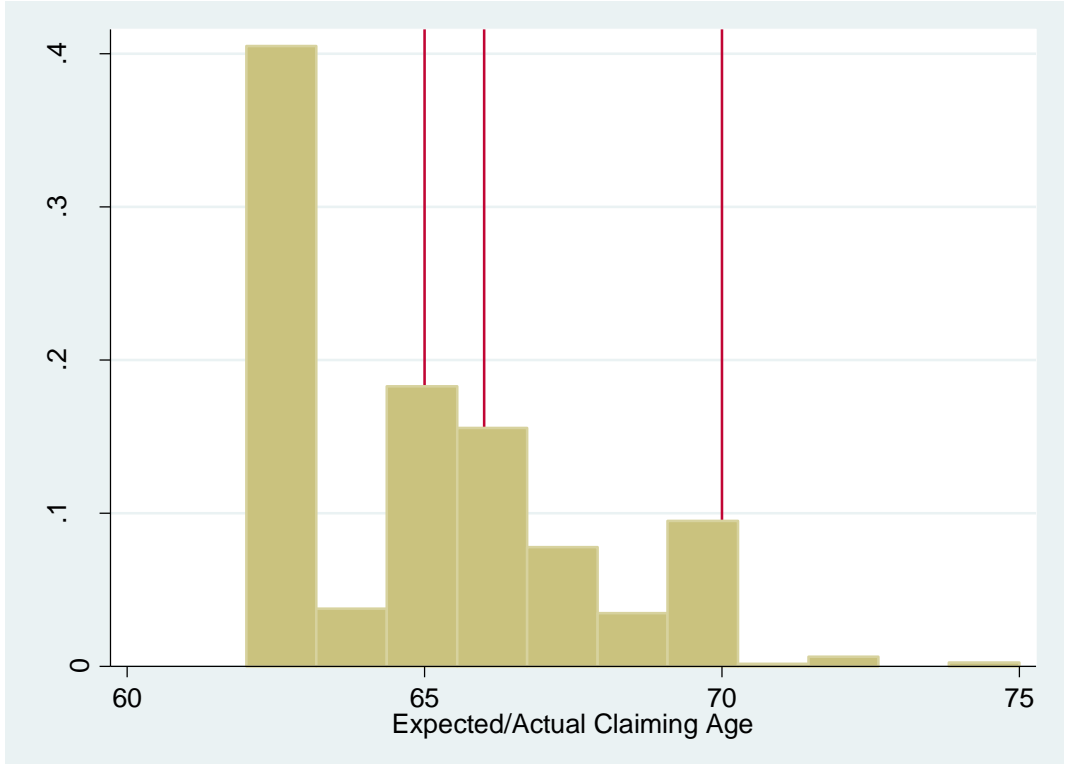

Figure 2: Distribution of (Claiming Age - Retirement Age)

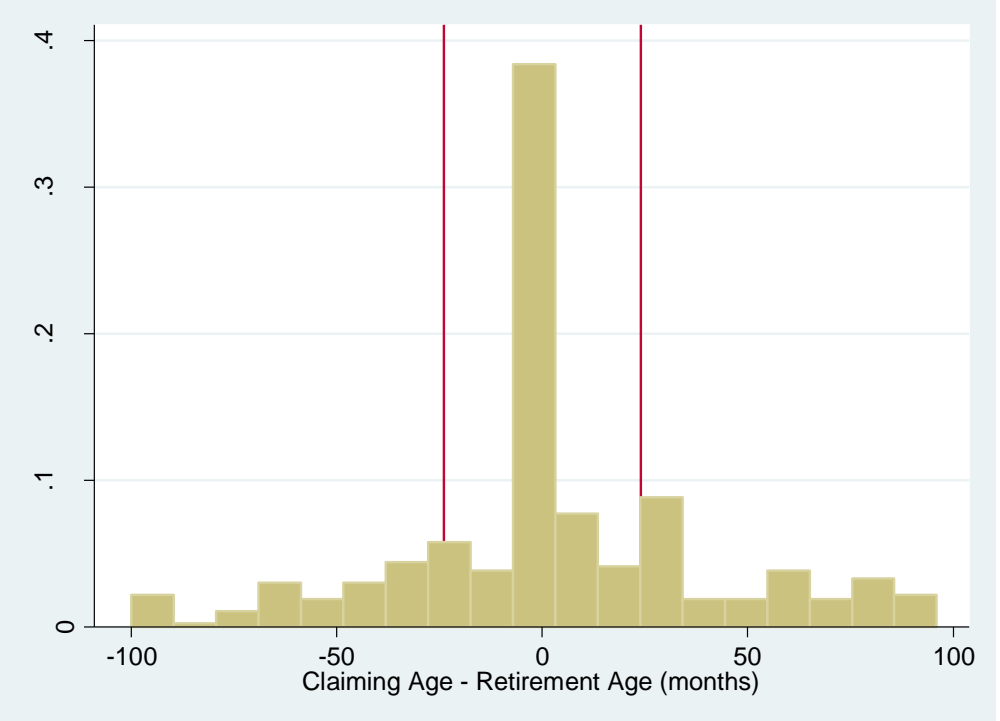

Notes: Based on sample of people who have both claimed and stopped work, and have a gap of less than 100 months between retirement and claiming. See text for details. 


\begin{tabular}{|c|c|c|c|c|c|c|c|}
\hline & \multicolumn{2}{|c|}{ Already Claimed $(N=558)$} & \multicolumn{2}{|c|}{ Not Yet Claimed $(N=558)$} & \multicolumn{3}{|c|}{ Full Sample $(N=1,116)$} \\
\hline & Mean & Std. Dev. & Mean & Std. Dev. & Mean & & \\
\hline Age & 71.21 & 6.21 & 59.17 & 3.32 & & 65.84 & 7.88 \\
\hline Actual/Expected Claiming Age & 63.64 & 2.06 & 66.31 & 2.69 & & 64.83 & 2.71 \\
\hline Working Full Time & 0.06 & 0.24 & 0.73 & 0.44 & & 0.36 & 0.48 \\
\hline Working Part Time & 0.23 & 0.42 & 0.11 & 0.32 & & 0.18 & 0.38 \\
\hline Unemployed & 0.05 & 0.21 & 0.05 & 0.22 & & 0.05 & 0.22 \\
\hline Out of Labor Force & 0.66 & 0.47 & 0.10 & 0.31 & & 0.41 & 0.49 \\
\hline Ever had IRA/401(k) & 0.75 & 0.43 & 0.79 & 0.41 & & 0.77 & 0.42 \\
\hline Married & 0.66 & 0.47 & 0.68 & 0.47 & & 0.67 & 0.47 \\
\hline Primary Earner & 0.74 & 0.44 & 0.80 & 0.40 & & 0.76 & 0.42 \\
\hline Male & 0.52 & 0.50 & 0.54 & 0.50 & & 0.53 & 0.50 \\
\hline Nonwhite & 0.20 & 0.40 & 0.28 & 0.45 & & 0.24 & 0.43 \\
\hline Bachelor's Degree & 0.35 & 0.48 & 0.39 & 0.49 & & 0.37 & 0.48 \\
\hline Good Health & 0.89 & 0.31 & 0.89 & 0.31 & & 0.89 & 0.31 \\
\hline Financial Literacy Score & 15.15 & 2.39 & 15.03 & 2.56 & & 15.10 & 2.46 \\
\hline Social Secrutiy Knowledge Score & 7.98 & 1.12 & 7.61 & 1.25 & & 7.81 & 1.19 \\
\hline "Benefits Unaffected by Start Age" & 0.08 & 0.28 & 0.09 & 0.29 & & 0.09 & 0.28 \\
\hline "Must Claim upon Retirement" & 0.06 & 0.24 & 0.10 & 0.30 & & 0.08 & 0.27 \\
\hline Retirement Age ( $N=409$ ) & 62.86 & 7.95 & & & & & \\
\hline Claiming Age - Retirement Age (months, $N=409$ ) & 0.50 & 7.64 & & & & & \\
\hline Claiming Age - Retirement Age $>2$ Years $(N=409)$ & 0.22 & 0.42 & & & & & \\
\hline
\end{tabular}

Notes: Based on individuals who have claimed or expect to claim worker benefits. Excludes individuals who report claiming or intending to claim before age 62. "Already Claimed" sample excludes people who have never worked. See text for details. Calculations use UAS post-stratification weights. 
Table 2: Correlates of Claiming Age

\begin{tabular}{|c|c|c|c|c|c|c|}
\hline VARIABLES & $\begin{array}{l}\text { Actual Claiming } \\
\text { Age in Months } \\
\text { (Already Claimed) }\end{array}$ & $\begin{array}{l}\text { Expected Claiming } \\
\text { Age in Months } \\
\text { (Not Yet Claimed) }\end{array}$ & $\begin{array}{l}\text { Actual/Expected } \\
\text { Claiming Age in } \\
\text { Months } \\
\text { (Combined } \\
\text { Sample) }\end{array}$ & $\begin{array}{l}\text { Actual Claiming } \\
\text { Age in Months } \\
\text { (Already Claimed) }\end{array}$ & $\begin{array}{l}\text { Expected Claiming } \\
\text { Age in Months } \\
\text { (Not Yet Claimed) }\end{array}$ & $\begin{array}{l}\text { Actual/Expected } \\
\text { Claiming Age in } \\
\text { Months } \\
\text { (Combined } \\
\text { Sample) }\end{array}$ \\
\hline Age & $\begin{array}{c}0.596 * * * \\
(0.208)\end{array}$ & $\begin{array}{c}0.655 \\
(0.502)\end{array}$ & $\begin{array}{c}0.613^{* * *} \\
(0.194)\end{array}$ & $\begin{array}{c}0.602^{* * *} \\
(0.212)\end{array}$ & $\begin{array}{c}0.613 \\
(0.505)\end{array}$ & $\begin{array}{c}0.606^{* * *} \\
(0.200)\end{array}$ \\
\hline Ever Had IRA/401(k) & $\begin{array}{c}4.443 \\
(3.260)\end{array}$ & $\begin{array}{c}7.798 \\
(5.094)\end{array}$ & $\begin{array}{c}5.728 * * \\
(2.869)\end{array}$ & $\begin{array}{c}4.670 \\
(2.962)\end{array}$ & $\begin{array}{c}6.113 \\
(4.790)\end{array}$ & $\begin{array}{l}5.072 * \\
(2.701)\end{array}$ \\
\hline Married & $\begin{array}{c}2.914 \\
(3.094)\end{array}$ & $\begin{array}{c}6.171 \\
(4.067)\end{array}$ & $\begin{array}{l}4.469 * \\
(2.463)\end{array}$ & $\begin{array}{c}3.067 \\
(3.001)\end{array}$ & $\begin{array}{c}5.942 \\
(3.988)\end{array}$ & $\begin{array}{l}4.496 * \\
(2.424)\end{array}$ \\
\hline Primary Earner & $\begin{array}{c}1.573 \\
(4.566)\end{array}$ & $\begin{array}{c}8.973 * * \\
(4.397)\end{array}$ & $\begin{array}{c}4.705 \\
(3.294)\end{array}$ & $\begin{array}{c}2.158 \\
(4.087)\end{array}$ & $\begin{array}{c}8.911 * * \\
(4.442)\end{array}$ & $\begin{array}{c}4.867 \\
(3.149)\end{array}$ \\
\hline Male & $\begin{array}{c}0.645 \\
(3.541)\end{array}$ & $\begin{array}{c}2.182 \\
(3.511)\end{array}$ & $\begin{array}{c}1.295 \\
(2.502)\end{array}$ & $\begin{array}{c}-0.717 \\
(3.315)\end{array}$ & $\begin{array}{c}1.459 \\
(3.353)\end{array}$ & $\begin{array}{c}0.307 \\
(2.444)\end{array}$ \\
\hline Nonwhite & $\begin{array}{c}1.675 \\
(4.179)\end{array}$ & $\begin{array}{l}-0.606 \\
(4.435)\end{array}$ & $\begin{array}{c}0.701 \\
(3.168)\end{array}$ & $\begin{array}{c}2.039 \\
(3.747)\end{array}$ & $\begin{array}{c}1.353 \\
(4.626)\end{array}$ & $\begin{array}{c}1.987 \\
(3.125)\end{array}$ \\
\hline Bachelor's Degree & $\begin{array}{c}7.461^{* * *} \\
(2.670)\end{array}$ & $\begin{array}{c}11.29 * * * \\
(3.483)\end{array}$ & $\begin{array}{c}9.239 * * * \\
(2.135)\end{array}$ & $\begin{array}{l}6.547^{* *} \\
(2.553)\end{array}$ & $\begin{array}{c}9.029 * * \\
(3.579)\end{array}$ & $\begin{array}{c}7.676^{* * *} \\
(2.133)\end{array}$ \\
\hline Good Health & $\begin{array}{l}-0.325 \\
(3.725)\end{array}$ & $\begin{array}{c}7.420 \\
(4.657)\end{array}$ & $\begin{array}{c}3.563 \\
(2.962)\end{array}$ & $\begin{array}{l}-0.918 \\
(3.829)\end{array}$ & $\begin{array}{c}7.523 \\
(4.694)\end{array}$ & $\begin{array}{c}3.366 \\
(3.002)\end{array}$ \\
\hline Financial Literacy Score & $\begin{array}{c}-0.967 \\
(0.652)\end{array}$ & $\begin{array}{l}-1.220 \\
(0.811)\end{array}$ & $\begin{array}{c}-1.048^{*} \\
(0.535)\end{array}$ & & & \\
\hline Social Security Knowledge Score & $\begin{array}{l}-0.898 \\
(1.440)\end{array}$ & $\begin{array}{l}-0.585 \\
(1.395)\end{array}$ & $\begin{array}{l}-0.770 \\
(1.006)\end{array}$ & & & \\
\hline "Benefits Unaffected by Start Age" & & & & $\begin{array}{c}3.303 \\
(4.689)\end{array}$ & $\begin{array}{c}0.253 \\
(9.115)\end{array}$ & $\begin{array}{c}1.444 \\
(4.979)\end{array}$ \\
\hline "Must Claim upon Retirement" & & & & $\begin{array}{c}12.36 \\
(8.622)\end{array}$ & $\begin{array}{c}2.171 \\
(5.997)\end{array}$ & $\begin{array}{c}6.534 \\
(5.462)\end{array}$ \\
\hline Already Claimed & & & $\begin{array}{c}-37.91 * * * \\
(2.748)\end{array}$ & & & $\begin{array}{c}-37.99 * * * \\
(2.803)\end{array}$ \\
\hline Constant & $\begin{array}{c}733.6^{* * *} \\
(17.03)\end{array}$ & $\begin{array}{c}750.2^{* * *} \\
(30.64)\end{array}$ & $\begin{array}{c}762.0 * * * \\
(13.82)\end{array}$ & $\begin{array}{c}711.2^{* * *} \\
(15.30)\end{array}$ & $\begin{array}{c}731.8^{* * *} \\
(29.84)\end{array}$ & $\begin{array}{c}741.4^{* * *} \\
(12.53)\end{array}$ \\
\hline Observations & 558 & 558 & 1,116 & 558 & 558 & 1,116 \\
\hline R-squared & 0.053 & 0.076 & 0.284 & 0.058 & 0.069 & 0.280 \\
\hline
\end{tabular}

Notes: Regressions use UAS post-stratification weights. Robust standard errors in parentheses.

*** $\mathrm{p}<0.01,{ }^{* *} \mathrm{p}<0.05, * \mathrm{p}<0.1$ 
Table 3: Correlates of Financial Literacy and Social Security Knowledge

\begin{tabular}{|c|c|c|c|c|}
\hline \multirow[b]{2}{*}{ VARIABLES } & \multirow[b]{2}{*}{$\begin{array}{c}\text { Financial Literacy } \\
\text { Score }\end{array}$} & \multicolumn{3}{|c|}{ "Benefits } \\
\hline & & $\begin{array}{c}\text { Social Security } \\
\text { Knowledge Score }\end{array}$ & $\begin{array}{l}\text { Unaffected by } \\
\text { Start Age" }\end{array}$ & $\begin{array}{l}\text { "Must Claim upon } \\
\text { Retirement" }\end{array}$ \\
\hline Age & $\begin{array}{c}0.0159 \\
(0.0113)\end{array}$ & $\begin{array}{c}0.0226 * * * \\
(0.00692)\end{array}$ & $\begin{array}{l}-0.000161 \\
(0.00168)\end{array}$ & $\begin{array}{c}-0.00343 * * * \\
(0.00132)\end{array}$ \\
\hline Ever Had IRA/401(k) & $\begin{array}{c}0.863 * * * \\
(0.251)\end{array}$ & $\begin{array}{c}0.446 * * * \\
(0.123)\end{array}$ & $\begin{array}{l}0.00588 \\
(0.0298)\end{array}$ & $\begin{array}{c}-0.0913 * * * \\
(0.0332)\end{array}$ \\
\hline Married & $\begin{array}{l}0.387^{*} \\
(0.222)\end{array}$ & $\begin{array}{l}0.0301 \\
(0.102)\end{array}$ & $\begin{array}{l}-0.0225 \\
(0.0290)\end{array}$ & $\begin{array}{c}-0.0644 * * * \\
(0.0212)\end{array}$ \\
\hline Primary Earner & $\begin{array}{l}-0.0450 \\
(0.251)\end{array}$ & $\begin{array}{c}0.167 \\
(0.126)\end{array}$ & $\begin{array}{c}0.0164 \\
(0.0341)\end{array}$ & $\begin{array}{l}-0.0413 \\
(0.0342)\end{array}$ \\
\hline Male & $\begin{array}{c}0.924 * * * \\
(0.203)\end{array}$ & $\begin{array}{c}0.101 \\
(0.103)\end{array}$ & $\begin{array}{l}-0.0246 \\
(0.0277)\end{array}$ & $\begin{array}{l}-0.00418 \\
(0.0257)\end{array}$ \\
\hline Nonwhite & $\begin{array}{c}-1.212 * * * \\
(0.263)\end{array}$ & $\begin{array}{c}-0.520 * * * \\
(0.132)\end{array}$ & $\begin{array}{l}0.0733^{*} \\
(0.0375)\end{array}$ & $\begin{array}{c}0.0424 \\
(0.0335)\end{array}$ \\
\hline Bachelor's Degree & $\begin{array}{c}1.456 * * * \\
(0.162)\end{array}$ & $\begin{array}{c}0.429 * * * \\
(0.0837)\end{array}$ & $\begin{array}{c}-0.0715 * * * \\
(0.0231)\end{array}$ & $\begin{array}{l}-0.0298 * \\
(0.0175)\end{array}$ \\
\hline Good Health & $\begin{array}{c}0.314 \\
(0.246)\end{array}$ & $\begin{array}{l}0.0514 \\
(0.173)\end{array}$ & $\begin{array}{l}-0.00354 \\
(0.0352)\end{array}$ & $\begin{array}{l}-0.0262 \\
(0.0358)\end{array}$ \\
\hline Constant & $\begin{array}{c}12.14^{* * *} \\
(0.833)\end{array}$ & $\begin{array}{c}5.699 * * * \\
(0.497)\end{array}$ & $\begin{array}{c}0.120 \\
(0.123)\end{array}$ & $\begin{array}{c}0.475^{* * *} \\
(0.103)\end{array}$ \\
\hline Observations & 1,116 & 1,116 & 1,116 & 1,116 \\
\hline R-squared & 0.255 & 0.148 & 0.034 & 0.065 \\
\hline
\end{tabular}

Notes: Regressions use UAS post-stratification weights. Robust standard errors in parentheses *** $\mathrm{p}<0.01,{ }^{* *} \mathrm{p}<0.05,{ }^{*} \mathrm{p}<0.1$ 
Table 4: Correlates of Relationship between Claiming and Retirement

\begin{tabular}{|c|c|c|c|c|c|c|}
\hline VARIABLES & Claim befor & Retirement & Claim at & tirement & Claim after & Retirement \\
\hline Age & $\begin{array}{c}0.0122 * * * \\
(0.00437)\end{array}$ & $\begin{array}{c}0.0130 * * * \\
(0.00420)\end{array}$ & $\begin{array}{l}0.000614 \\
(0.00351)\end{array}$ & $\begin{array}{l}0.000553 \\
(0.00356)\end{array}$ & $\begin{array}{c}-0.0129 * * * \\
(0.00453)\end{array}$ & $\begin{array}{c}-0.0135 * * * \\
(0.00454)\end{array}$ \\
\hline FRA $>$ Claiming Age $>62$ & $\begin{array}{c}0.0550 \\
(0.0623)\end{array}$ & $\begin{array}{c}0.0428 \\
(0.0617)\end{array}$ & $\begin{array}{c}0.0721 \\
(0.0523)\end{array}$ & $\begin{array}{c}0.0655 \\
(0.0509)\end{array}$ & $\begin{array}{c}-0.127^{* *} \\
(0.0644)\end{array}$ & $\begin{array}{l}-0.108 * \\
(0.0645)\end{array}$ \\
\hline FRA $\leq$ Claiming age $\leq$ FRA +6 months & $\begin{array}{c}0.185^{*} \\
(0.0995)\end{array}$ & $\begin{array}{c}0.194 * \\
(0.0996)\end{array}$ & $\begin{array}{c}0.0604 \\
(0.0728)\end{array}$ & $\begin{array}{c}0.0545 \\
(0.0788)\end{array}$ & $\begin{array}{c}-0.245^{* *} \\
(0.0983)\end{array}$ & $\begin{array}{c}-0.248 * * * \\
(0.0912)\end{array}$ \\
\hline Claiming Age $>$ FRA +6 months & $\begin{array}{c}-0.131 \\
(0.0932)\end{array}$ & $\begin{array}{c}-0.138 \\
(0.0891)\end{array}$ & $\begin{array}{c}0.0791 \\
(0.0987)\end{array}$ & $\begin{array}{l}0.0952 \\
(0.100)\end{array}$ & $\begin{array}{l}0.0520 \\
(0.122)\end{array}$ & $\begin{array}{l}0.0429 \\
(0.117)\end{array}$ \\
\hline Ever Had IRA/401(k) & $\begin{array}{l}-0.0143 \\
(0.0767)\end{array}$ & $\begin{array}{l}0.00380 \\
(0.0743)\end{array}$ & $\begin{array}{c}0.0534 \\
(0.0636)\end{array}$ & $\begin{array}{c}0.0533 \\
(0.0616)\end{array}$ & $\begin{array}{l}-0.0390 \\
(0.0770)\end{array}$ & $\begin{array}{l}-0.0571 \\
(0.0745)\end{array}$ \\
\hline Married & $\begin{array}{c}0.0402 \\
(0.0730)\end{array}$ & $\begin{array}{c}0.0550 \\
(0.0692)\end{array}$ & $\begin{array}{l}-0.0124 \\
(0.0622)\end{array}$ & $\begin{array}{l}-0.0215 \\
(0.0634)\end{array}$ & $\begin{array}{l}-0.0278 \\
(0.0821)\end{array}$ & $\begin{array}{l}-0.0335 \\
(0.0789)\end{array}$ \\
\hline Primary Earner & $\begin{array}{l}-0.0565 \\
(0.0836)\end{array}$ & $\begin{array}{l}-0.0433 \\
(0.0818)\end{array}$ & $\begin{array}{l}-0.0891 \\
(0.0780)\end{array}$ & $\begin{array}{l}-0.0848 \\
(0.0782)\end{array}$ & $\begin{array}{c}0.146 * \\
(0.0757)\end{array}$ & $\begin{array}{c}0.128^{*} \\
(0.0762)\end{array}$ \\
\hline Male & $\begin{array}{l}0.00877 \\
(0.0723)\end{array}$ & $\begin{array}{c}0.0167 \\
(0.0680)\end{array}$ & $\begin{array}{c}0.118^{*} \\
(0.0688)\end{array}$ & $\begin{array}{c}0.107 \\
(0.0662)\end{array}$ & $\begin{array}{l}-0.127^{*} \\
(0.0714)\end{array}$ & $\begin{array}{l}-0.124 * \\
(0.0682)\end{array}$ \\
\hline Nonwhite & $\begin{array}{c}0.132 \\
(0.0944)\end{array}$ & $\begin{array}{c}0.119 \\
(0.0880)\end{array}$ & $\begin{array}{l}-0.131 * * \\
(0.0666)\end{array}$ & $\begin{array}{l}-0.121 * \\
(0.0651)\end{array}$ & $\begin{array}{l}-0.00127 \\
(0.0886)\end{array}$ & $\begin{array}{l}0.00215 \\
(0.0847)\end{array}$ \\
\hline Bachelor's Degree & $\begin{array}{l}-0.0702 \\
(0.0618)\end{array}$ & $\begin{array}{l}-0.0668 \\
(0.0587)\end{array}$ & $\begin{array}{l}-0.0486 \\
(0.0506)\end{array}$ & $\begin{array}{l}-0.0652 \\
(0.0483)\end{array}$ & $\begin{array}{c}0.119 * \\
(0.0632)\end{array}$ & $\begin{array}{l}0.132 * * \\
(0.0618)\end{array}$ \\
\hline Good Health & $\begin{array}{l}-0.0522 \\
(0.0912)\end{array}$ & $\begin{array}{l}-0.0405 \\
(0.0862)\end{array}$ & $\begin{array}{l}-0.0648 \\
(0.0909)\end{array}$ & $\begin{array}{l}-0.0678 \\
(0.0892)\end{array}$ & $\begin{array}{c}0.117 \\
(0.0941)\end{array}$ & $\begin{array}{c}0.108 \\
(0.0950)\end{array}$ \\
\hline Financial Literacy Score & $\begin{array}{l}0.00782 \\
(0.0150)\end{array}$ & & $\begin{array}{c}-0.0174 \\
(0.0117)\end{array}$ & & $\begin{array}{l}0.00957 \\
(0.0158)\end{array}$ & \\
\hline Social Security Knowledge Score & $\begin{array}{c}0.0204 \\
(0.0278)\end{array}$ & & $\begin{array}{c}0.0150 \\
(0.0298)\end{array}$ & & $\begin{array}{l}-0.0354 \\
(0.0302)\end{array}$ & \\
\hline "Benefits Unaffected by Start Age" & & $\begin{array}{c}-0.156 \\
(0.115)\end{array}$ & & $\begin{array}{l}0.00928 \\
(0.0975)\end{array}$ & & $\begin{array}{c}0.147 \\
(0.108)\end{array}$ \\
\hline "Must Claim upon Retirement" & & $\begin{array}{c}0.143 \\
(0.118)\end{array}$ & & $\begin{array}{l}0.0887 \\
(0.101)\end{array}$ & & $\begin{array}{c}-0.232^{*} \\
(0.129)\end{array}$ \\
\hline \multicolumn{7}{|l|}{ Constant } \\
\hline Observations & 409 & 409 & 409 & 409 & 409 & 409 \\
\hline
\end{tabular}

Notes: Coefficients are marginal effects from a multinomial logit model. Regressions use UAS post-stratification weights.

Robust standard errors in parentheses

$* * * p<0.01, * * p<0.05, * p<0.1$ 
Table 5: Means of Financing Gap between Retirement and Claiming

Response

Percent

I/we used our savings

$23.2 \%$

I/we relied on income from an employer-sponsored pension

$61.7 \%$

I/we relied on my spouse's income or Social Security benefit

$19.0 \%$

I/we relied on help from family and friends

$0.0 \%$

I/we took out a loan

$1.2 \%$

I/we refinanced a mortgage

$1.2 \%$

Other

$14.6 \%$

Notes: Based on 96 out of the 97 individuals who had a gap of more than 2 years between retirement and claiming. Calculations use UAS poststratification weights. 
Table 6: Satisfaction with Claiming Decision

"I am satisfied with my decision on when to start Social Security Benefits"

$(N=557)$

Strongly Disagree $3.91 \%$

Disagree $\quad 7.36 \%$

Neither Agree Nor Disagree $\quad 9.73 \%$

Agree

$44.35 \%$

Strongly Agree

$34.64 \%$

Notes: Calculations use UAS post-

stratification weights. 
Table 7: Correlates of Satisfaction with Claiming Decision

\begin{tabular}{|c|c|c|c|}
\hline \multirow{2}{*}{$\begin{array}{l}\text { VARIABLES } \\
\text { Age }\end{array}$} & \multicolumn{3}{|c|}{ (1 = Strongly Disagree, 5 = Strongly Agree) } \\
\hline & -0.00177 & -0.00347 & -0.00327 \\
\hline & $(0.00869)$ & $(0.00888)$ & $(0.00877)$ \\
\hline \multirow[t]{2}{*}{ FRA $>$ Claiming Age $>62$} & -0.0521 & -0.0578 & -0.0638 \\
\hline & $(0.135)$ & $(0.125)$ & $(0.125)$ \\
\hline \multirow[t]{2}{*}{$\mathrm{FRA} \leq$ Claiming age $\leq \mathrm{FRA}+6$ months } & $0.370^{*}$ & $0.354^{*}$ & $0.367^{* *}$ \\
\hline & $(0.198)$ & $(0.183)$ & $(0.178)$ \\
\hline \multirow[t]{2}{*}{ Claiming Age $>$ FRA + 6 months } & 0.288 & 0.253 & 0.247 \\
\hline & $(0.192)$ & $(0.193)$ & $(0.188)$ \\
\hline \multirow[t]{2}{*}{ Claiming Age - Retirement Age $>2$ Years } & $0.275^{* *}$ & $0.240^{*}$ & $0.233^{*}$ \\
\hline & $(0.127)$ & $(0.125)$ & $(0.125)$ \\
\hline \multirow[t]{2}{*}{ Ever Had IRA/401(k) } & & 0.155 & 0.173 \\
\hline & & $(0.148)$ & $(0.160)$ \\
\hline \multirow[t]{2}{*}{ Married } & & 0.0525 & 0.0536 \\
\hline & & $(0.127)$ & (0.124) \\
\hline \multirow[t]{2}{*}{ Primary Earner } & & 0.226 & 0.242 \\
\hline & & $(0.157)$ & $(0.156)$ \\
\hline \multirow[t]{2}{*}{ Male } & & $0.266 * *$ & $0.256 * *$ \\
\hline & & $(0.131)$ & $(0.122)$ \\
\hline \multirow[t]{2}{*}{ Nonwhite } & & -0.201 & -0.202 \\
\hline & & $(0.185)$ & $(0.166)$ \\
\hline \multirow[t]{2}{*}{ Bachelor's Degree } & & -0.0421 & -0.0562 \\
\hline & & $(0.117)$ & $(0.106)$ \\
\hline \multirow[t]{2}{*}{ Good Health } & & 0.0506 & 0.0562 \\
\hline & & $(0.111)$ & $(0.114)$ \\
\hline \multirow[t]{2}{*}{ Financial Literacy Score } & & -0.00566 & \\
\hline & & $(0.0313)$ & \\
\hline \multirow[t]{2}{*}{ Social Security Knowledge Score } & & 0.0450 & \\
\hline & & $(0.0530)$ & \\
\hline \multirow[t]{2}{*}{ "Benefits Unaffected by Start Age" } & & & -0.221 \\
\hline & & & $(0.219)$ \\
\hline \multirow[t]{2}{*}{ "Must Claim upon Retirement" } & & & -0.0177 \\
\hline & & & $(0.330)$ \\
\hline \multirow[t]{2}{*}{ Constant } & $4.025^{* * *}$ & $3.439 * * *$ & $3.700 * * *$ \\
\hline & $(0.629)$ & $(0.892)$ & $(0.674)$ \\
\hline Observations & 557 & 557 & 557 \\
\hline R-squared & 0.026 & 0.079 & 0.080 \\
\hline
\end{tabular}

Notes: Regressions use UAS post-stratification weights. Robust standard errors in parentheses.

$* * * p<0.01, * * p<0.05, * p<0.1$ 


\begin{tabular}{lr}
\hline \multicolumn{1}{c}{ Claimed Before FRA (N =444) } & Percent \\
\hline Reason & $21.2 \%$ \\
l/we needed the money & $14.8 \%$ \\
l/we didn't trust that Social Security wouldn't cut benefits in the future & $14.4 \%$ \\
l/we felt like our health wasn't so good and that I/we might not enjoy a long life & $8.6 \%$ \\
l/we thought that I/we could invest the money and end up ahead & $38.4 \%$ \\
I had stopped working & $8.0 \%$ \\
My spouse had stopped working & $1.3 \%$ \\
I wanted my spouse to be able to claim a benefit on my record & $4.6 \%$ \\
l/we were encouraged to claim by a financial adviser & $2.4 \%$ \\
l/we were encouraged to claim by an employee at the Social Security office & $6.9 \%$ \\
l/we were encouraged to claim by friends or family & $21.9 \%$ \\
Other &
\end{tabular}

\begin{tabular}{lr}
\hline \multicolumn{1}{c}{ Claimed at FRA or within 6 months of reaching FRA (N =64) } \\
\hline Reason & Percent \\
The earnings test no longer applies at full retirement age & $7.6 \%$ \\
I wanted to avoid getting a reduced benefit & $18.5 \%$ \\
It seemed natural to start my benefit at my full retirement age & $45.7 \%$ \\
That's when I stopped working & $25.1 \%$ \\
That's when my spouse stopped working & $0.0 \%$ \\
Even though I had stopped working before full retirement age, my retirement savings (or my \\
spouse/partner's) was enough to pay our expenses through full retirement age (but not later) \\
l/we didn't want to delay any longer as there is a risk that Social Security might cut benefits in the \\
future & $2.9 \%$ \\
l/we didn't think it was worth it to delay any longer as our health wasn't so good and I/we might not & $14.9 \%$ \\
enjoy a long life & $5.2 \%$ \\
l/we didn't want to delay any longer as I/we could invest the money and end up ahead & $14.9 \%$ \\
l/we were encouraged to claim at full retirement age by a financial adviser & $10.2 \%$ \\
l/we were encouraged to claim at full retirement age by friends or family & $12.7 \%$ \\
l/we were encouraged to claim at full retirement age by an employee at the Social Security office & $7.3 \%$ \\
Other & $9.9 \%$ \\
\hline \multicolumn{1}{c}{ Claimed More than 6 Months after FRA ( $N=46)$} \\
\hline I was still working & $46.1 \%$ \\
My spouse was still working & $4.6 \%$ \\
l/we didn't need the money yet & $34.9 \%$ \\
Even though I had stopped working, my retirement savings (or my spouse/partner's) was enough to & \\
pay our expenses & $5.3 \%$ \\
I wanted my benefit to grow through delay & $31.1 \%$ \\
l/we felt that it was worth it to delay because our health was good and I/we would likely enjoy a long & \\
life & $17.2 \%$ \\
l/we were encouraged to delay by a financial adviser & $2.7 \%$ \\
l/we were encouraged to delay by a friend or family member & $7.1 \%$ \\
l/we were encouraged to delay by an employee at the Social Security office & $6.2 \%$ \\
Other (Please specify) & $12.8 \%$ \\
&
\end{tabular}

\begin{tabular}{lr}
\hline \multicolumn{1}{c}{ Have Not Claimed Yet and Age $\geq 62$ (N=125) } \\
\hline I am still working & $65.3 \%$ \\
My spouse/partner is still working & $11.7 \%$ \\
l/we don't need the money yet & $13.6 \%$ \\
I have not yet reached full retirement age & $36.5 \%$ \\
Even though I have stopped working, my retirement savings (or my spouse/partner's) is enough to & $4.3 \%$ \\
pay our expenses & $45.2 \%$ \\
To take advantage of larger benefits in the future by claiming later & $20.6 \%$ \\
l/we feel delay is worth it because our health is good and l/we are likely to enjoy a long life & $0.0 \%$ \\
l/we were encouraged to postpone collecting my benefits by a friend or family member & $4.6 \%$ \\
l/we were encouraged to postpone collecting my benefits by a financial professional & $0.0 \%$ \\
l/we were encouraged to delay by an employee at the Social Security office & $5.8 \%$ \\
Other & \\
\hline
\end{tabular}

Notes: Calculations use UAS post-stratification weights. 
Table 9: Relationship between Reasons for Claiming and Satisfaction with Decision

\begin{tabular}{|c|c|c|c|c|c|}
\hline \multicolumn{2}{|c|}{ Early Claimers } & \multicolumn{2}{|c|}{ Full Retirement Age Claimers } & \multicolumn{2}{|c|}{ Late Claimers } \\
\hline Needed Money & $\begin{array}{c}-0.398 * * \\
(0.161)\end{array}$ & Earnings Test & $\begin{array}{l}-0.349 \\
(0.367)\end{array}$ & Still Working & $\begin{array}{l}-0.276 \\
(0.381)\end{array}$ \\
\hline Feared Benefit Cut & $\begin{array}{c}-0.191 \\
(0.184)\end{array}$ & Avoid Reduction & $\begin{array}{l}0.389 * \\
(0.231)\end{array}$ & Spouse Still Working & $\begin{array}{c}1.444 * * \\
(0.702)\end{array}$ \\
\hline Poor Health & $\begin{array}{c}-0.391 * * \\
(0.181)\end{array}$ & Seemed Natural & $\begin{array}{c}0.331 \\
(0.227)\end{array}$ & Didn't Need Money & $\begin{array}{c}0.105 \\
(0.428)\end{array}$ \\
\hline Invest Money & $\begin{array}{c}0.150 \\
(0.203)\end{array}$ & Stopped Work & $\begin{array}{l}-0.117 \\
(0.192)\end{array}$ & Enough Saved & $\begin{array}{c}0.530 \\
(0.466)\end{array}$ \\
\hline Stopped Work & $\begin{array}{l}0.0430 \\
(0.130)\end{array}$ & Spouse Stopped Work & - & Gains from Delay & $\begin{array}{c}-0.878 * \\
(0.467)\end{array}$ \\
\hline Spouse Stopped Work & $\begin{array}{l}-0.403 \\
(0.249)\end{array}$ & Enough Saved & $\begin{array}{c}-2.380 * * \\
(0.998)\end{array}$ & Good Health & $\begin{array}{r}-0.0244 \\
(0.484)\end{array}$ \\
\hline Spousal Benefit & $\begin{array}{c}-0.205 \\
(0.310)\end{array}$ & Feared Benefit Cut & $\begin{array}{c}-0.936 \\
(0.576)\end{array}$ & Financial Adviser & $\begin{array}{l}0.0635 \\
(0.572)\end{array}$ \\
\hline Financial Adviser & $\begin{array}{c}0.472 * * * \\
(0.149)\end{array}$ & Poor Health & $\begin{array}{l}1.530 * \\
(0.819)\end{array}$ & Family or Friends & $\begin{array}{c}-0.675 * \\
(0.355)\end{array}$ \\
\hline SSA Employee & $\begin{array}{l}-0.698 \\
(0.517)\end{array}$ & Invest Money & $\begin{array}{c}0.732 * * * \\
(0.230)\end{array}$ & SSA Employee & $\begin{array}{l}-0.113 \\
(0.594)\end{array}$ \\
\hline Family or Friends & $\begin{array}{c}0.311^{* *} \\
(0.136)\end{array}$ & Financial Adviser & $\begin{array}{c}0.306 \\
(0.238)\end{array}$ & Other & $\begin{array}{l}0.0494 \\
(0.543)\end{array}$ \\
\hline Other & $\begin{array}{c}-0.397^{* *} \\
(0.180)\end{array}$ & Family or Friends & $\begin{array}{c}-0.733 \\
(0.713)\end{array}$ & & \\
\hline & & $\begin{array}{l}\text { SSA Employee } \\
\text { Other }\end{array}$ & $\begin{array}{c}0.799 * * \\
(0.391) \\
0.332 \\
(0.261)\end{array}$ & & \\
\hline Observations & 443 & Observations & 64 & Observations & 46 \\
\hline R-squared & 0.098 & R-squared & 0.501 & R-squared & 0.191 \\
\hline
\end{tabular}

Notes: Regressions use UAS post-stratification weights. Robust standard errors in parentheses. Constant term not reported.

$* * * p<0.01, * * p<0.05, * p<0.1$ 
Table 10: Awareness of Social Security Rules and Influence on Claiming Decisions

Monthly Social Security benefits increase by about 8 percent for each year you delay starting them between age 62 and 70

\begin{tabular}{lr}
\hline Not aware of the rule & $13.0 \%$ \\
Aware but no influence & $54.6 \%$ \\
Aware and some influence & $25.6 \%$ \\
Aware and a great deal of influence & $6.8 \%$ \\
\hline \multicolumn{2}{c}{ Social Security benefits for widows and widowers are based on the higher of the two } \\
\multicolumn{2}{c}{ spouses' individual Social Security benefits } \\
\hline Not aware of the rule & $15.3 \%$ \\
Aware but no influence & $54.1 \%$ \\
Aware and some influence & $19.9 \%$ \\
Aware and a great deal of influence & $10.8 \%$ \\
\hline
\end{tabular}

Notes: Top panel based on 403 individuals who have claimed worker benefits and were born in 1943 or later. Bottom panel based on subset of 183 married primary earners. Calculations use UAS post-stratification weights. 


\begin{tabular}{|c|c|c|c|c|c|c|c|c|c|c|c|c|c|c|c|c|}
\hline \multirow{3}{*}{$\begin{array}{l}\text { VARIABLES } \\
\text { FRA }>\text { Claiming Age }>62\end{array}$} & \multicolumn{8}{|c|}{ Benefits increase by $8 \%$ per year with delay } & \multicolumn{8}{|c|}{ Survivor benefit based on higher of two spouses' benefits } \\
\hline & \multicolumn{2}{|c|}{ Not aware } & \multicolumn{2}{|c|}{$\begin{array}{c}\text { Aware but no } \\
\text { influence }\end{array}$} & \multicolumn{2}{|c|}{$\begin{array}{c}\text { Aware and some } \\
\text { influence }\end{array}$} & \multicolumn{2}{|c|}{$\begin{array}{c}\text { Aware and great } \\
\text { influence }\end{array}$} & \multicolumn{2}{|c|}{ Not aware } & \multicolumn{2}{|c|}{$\begin{array}{c}\text { Aware but no } \\
\text { influence }\end{array}$} & \multicolumn{2}{|c|}{$\begin{array}{l}\text { Aware and some } \\
\text { influence }\end{array}$} & \multicolumn{2}{|c|}{$\begin{array}{l}\text { Aware and great } \\
\text { influence }\end{array}$} \\
\hline & $\begin{array}{l}0.0733^{*} \\
(0.0411)\end{array}$ & $\begin{array}{c}0.0820^{* *} \\
(0.0407)\end{array}$ & $\begin{array}{l}-0.0979 \\
(0.0660)\end{array}$ & $\begin{array}{c}-0.100 \\
(0.0673)\end{array}$ & $\begin{array}{c}0.0161 \\
(0.0589)\end{array}$ & $\begin{array}{c}0.0130 \\
(0.0618)\end{array}$ & $\begin{array}{l}0.00844 \\
(0.0204)\end{array}$ & $\begin{array}{l}0.00534 \\
(0.0168)\end{array}$ & $\begin{array}{c}0.0954 \\
(0.0679)\end{array}$ & $\begin{array}{c}0.101 \\
(0.0689)\end{array}$ & $\begin{array}{l}0.00524 \\
(0.0960)\end{array}$ & $\begin{array}{l}0.00110 \\
(0.0975)\end{array}$ & $\begin{array}{c}-0.104 \\
(0.0780)\end{array}$ & $\begin{array}{c}-0.102 \\
(0.0814)\end{array}$ & $\begin{array}{l}0.00303 \\
(0.0405)\end{array}$ & $\begin{array}{c}-0.000281 \\
(0.0419)\end{array}$ \\
\hline$F R A \leq$ Claiming age $\leq F R A+6$ months & $\begin{array}{c}0.108 \\
(0.0788)\end{array}$ & $\begin{array}{c}0.106 \\
(0.0748)\end{array}$ & $\begin{array}{c}-0.358^{* * *} \\
(0.0904)\end{array}$ & $\begin{array}{c}-0.358^{* * *} \\
(0.0893)\end{array}$ & $\begin{array}{c}0.118 \\
(0.0913)\end{array}$ & $\begin{array}{c}0.107 \\
(0.0947)\end{array}$ & $\begin{array}{l}0.132^{* *} \\
(0.0535)\end{array}$ & $\begin{array}{l}0.146^{* * *} \\
(0.0556)\end{array}$ & $\begin{array}{l}-0.0785 \\
(0.0626)\end{array}$ & $\begin{array}{l}-0.0649 \\
(0.0647)\end{array}$ & $\begin{array}{c}-0.00673 \\
(0.132)\end{array}$ & $\begin{array}{l}0.0108 \\
(0.129)\end{array}$ & $\begin{array}{c}0.00413 \\
(0.123)\end{array}$ & $\begin{array}{l}-0.0340 \\
(0.109)\end{array}$ & $\begin{array}{c}0.0811 \\
(0.0674)\end{array}$ & $\begin{array}{c}0.0881 \\
(0.0737)\end{array}$ \\
\hline Claiming Age $>$ FRA +6 months & $\begin{array}{c}0.0469 \\
(0.0867)\end{array}$ & $\begin{array}{c}0.0779 \\
(0.0960)\end{array}$ & $\begin{array}{c}-0.404 * * * \\
(0.106)\end{array}$ & $\begin{array}{c}-0.408^{* * *} \\
(0.109)\end{array}$ & $\begin{array}{l}0.0337 \\
(0.106)\end{array}$ & $\begin{array}{l}0.0362 \\
(0.125)\end{array}$ & $\begin{array}{c}0.324^{* * *} \\
(0.0723)\end{array}$ & $\begin{array}{l}0.294 * * * \\
(0.0993)\end{array}$ & $\begin{array}{l}0.00145 \\
(0.0968)\end{array}$ & $\begin{array}{l}0.00642 \\
(0.0936)\end{array}$ & $\begin{array}{c}-0.349 * * * \\
(0.134)\end{array}$ & $\begin{array}{c}-0.365^{* * *} \\
(0.131)\end{array}$ & $\begin{array}{l}0.0711 \\
(0.162)\end{array}$ & $\begin{array}{l}0.0793 \\
(0.150)\end{array}$ & $\begin{array}{l}0.277^{* *} \\
(0.133)\end{array}$ & $\begin{array}{l}0.279^{*} \\
(0.145)\end{array}$ \\
\hline Claiming Age - Retirement Age $>2$ Years & $\begin{array}{c}0.0406 \\
(0.0574)\end{array}$ & $\begin{array}{c}0.0438 \\
(0.0592)\end{array}$ & $\begin{array}{l}0.00707 \\
(0.0761)\end{array}$ & $\begin{array}{l}-0.00244 \\
(0.0791)\end{array}$ & $\begin{array}{l}-0.0859 \\
(0.0644)\end{array}$ & $\begin{array}{l}-0.0903 \\
(0.0670)\end{array}$ & $\begin{array}{c}0.0382 \\
(0.0372)\end{array}$ & $\begin{array}{c}0.0489 \\
(0.0424)\end{array}$ & $\begin{array}{l}0.00371 \\
(0.0816)\end{array}$ & $\begin{array}{l}-0.00540 \\
(0.0819)\end{array}$ & $\begin{array}{l}0.0644 \\
(0.109)\end{array}$ & $\begin{array}{l}0.0563 \\
(0.111)\end{array}$ & $\begin{array}{l}-0.0160 \\
(0.0884)\end{array}$ & $\begin{array}{l}0.00908 \\
(0.0870)\end{array}$ & $\begin{array}{l}-0.0522 \\
(0.0570)\end{array}$ & $\begin{array}{l}-0.0600 \\
(0.0543)\end{array}$ \\
\hline Age & $\begin{array}{c}0.00167 \\
(0.00732)\end{array}$ & $\begin{array}{l}-0.000618 \\
(0.00708)\end{array}$ & $\begin{array}{c}0.0129 \\
(0.00997)\end{array}$ & $\begin{array}{c}0.0130 \\
(0.00993)\end{array}$ & $\begin{array}{c}-0.0101 \\
(0.00858)\end{array}$ & $\begin{array}{l}-0.00852 \\
(0.00902)\end{array}$ & $\begin{array}{l}-0.00449 \\
(0.00443)\end{array}$ & $\begin{array}{l}-0.00386 \\
(0.00449)\end{array}$ & $\begin{array}{c}0.0129 \\
(0.0111)\end{array}$ & $\begin{array}{c}0.0130 \\
(0.0113)\end{array}$ & $\begin{array}{l}-0.0222 \\
(0.0140)\end{array}$ & $\begin{array}{l}-0.0226 \\
(0.0143)\end{array}$ & $\begin{array}{l}0.000627 \\
(0.0104)\end{array}$ & $\begin{array}{l}-0.00100 \\
(0.00959)\end{array}$ & $\begin{array}{c}0.00866 \\
(0.00850)\end{array}$ & $\begin{array}{c}0.0106 \\
(0.00738)\end{array}$ \\
\hline Ever Had IRA/401(k) & $\begin{array}{l}-0.0119 \\
(0.0450)\end{array}$ & $\begin{array}{l}-0.0307 \\
(0.0469)\end{array}$ & $\begin{array}{c}0.0373 \\
(0.0745)\end{array}$ & $\begin{array}{c}0.0348 \\
(0.0781)\end{array}$ & $\begin{array}{l}-0.0150 \\
(0.0708)\end{array}$ & $\begin{array}{l}-0.0196 \\
(0.0760)\end{array}$ & $\begin{array}{l}-0.0103 \\
(0.0420)\end{array}$ & $\begin{array}{c}0.0155 \\
(0.0572)\end{array}$ & $\begin{array}{l}0.0318 \\
(0.101)\end{array}$ & $\begin{array}{c}0.0538 \\
(0.0954)\end{array}$ & $\begin{array}{c}-0.00143 \\
(0.137)\end{array}$ & $\begin{array}{l}0.0295 \\
(0.127)\end{array}$ & $\begin{array}{l}-0.0931 \\
(0.0909)\end{array}$ & $\begin{array}{l}-0.171^{* *} \\
(0.0812)\end{array}$ & $\begin{array}{l}0.0627 \\
(0.110)\end{array}$ & $\begin{array}{l}0.0879 \\
(0.103)\end{array}$ \\
\hline Married & $\begin{array}{l}-0.0518 \\
(0.0596)\end{array}$ & $\begin{array}{l}-0.0592 \\
(0.0592)\end{array}$ & $\begin{array}{c}0.0207 \\
(0.0761)\end{array}$ & $\begin{array}{l}0.00953 \\
(0.0764)\end{array}$ & $\begin{array}{c}0.0455 \\
(0.0681)\end{array}$ & $\begin{array}{c}0.0377 \\
(0.0730)\end{array}$ & $\begin{array}{l}-0.0144 \\
(0.0319)\end{array}$ & $\begin{array}{c}0.0119 \\
(0.0304)\end{array}$ & & & & & & & & \\
\hline Primary Earner & $\begin{array}{l}-0.0727 \\
(0.0753)\end{array}$ & $\begin{array}{l}-0.0741 \\
(0.0726)\end{array}$ & $\begin{array}{c}-0.104 \\
(0.0826)\end{array}$ & $\begin{array}{c}-0.114 \\
(0.0821)\end{array}$ & $\begin{array}{c}0.0911 \\
(0.0680)\end{array}$ & $\begin{array}{c}0.0998 \\
(0.0716)\end{array}$ & $\begin{array}{c}0.0851^{* * *} \\
(0.0188)\end{array}$ & $\begin{array}{c}0.0880^{* * *} \\
(0.0196)\end{array}$ & & & & & & & & \\
\hline Male & $\begin{array}{l}-0.0316 \\
(0.0446)\end{array}$ & $\begin{array}{l}-0.0538 \\
(0.0452)\end{array}$ & $\begin{array}{c}0.0149 \\
(0.0677)\end{array}$ & $\begin{array}{c}0.0303 \\
(0.0660)\end{array}$ & $\begin{array}{c}0.0310 \\
(0.0622)\end{array}$ & $\begin{array}{c}0.0214 \\
(0.0665)\end{array}$ & $\begin{array}{l}-0.0143 \\
(0.0320)\end{array}$ & $\begin{array}{l}0.00216 \\
(0.0296)\end{array}$ & $\begin{array}{c}0.0865 \\
(0.0725)\end{array}$ & $\begin{array}{c}0.0829 \\
(0.0617)\end{array}$ & $\begin{array}{l}-0.0564 \\
(0.107)\end{array}$ & $\begin{array}{l}-0.0119 \\
(0.0989)\end{array}$ & $\begin{array}{l}-0.0405 \\
(0.0894)\end{array}$ & $\begin{array}{l}-0.0815 \\
(0.0808)\end{array}$ & $\begin{array}{c}0.0105 \\
(0.0607)\end{array}$ & $\begin{array}{c}0.0105 \\
(0.0614)\end{array}$ \\
\hline Nonwhite & $\begin{array}{c}0.0374 \\
(0.0690)\end{array}$ & $\begin{array}{c}0.0806 \\
(0.0760)\end{array}$ & $\begin{array}{l}-0.0162 \\
(0.0860)\end{array}$ & $\begin{array}{l}-0.0314 \\
(0.0872)\end{array}$ & $\begin{array}{l}-0.0483 \\
(0.0731)\end{array}$ & $\begin{array}{l}-0.0475 \\
(0.0805)\end{array}$ & $\begin{array}{c}0.0271 \\
(0.0508)\end{array}$ & $\begin{array}{l}-0.00173 \\
(0.0285)\end{array}$ & $\begin{array}{c}0.0702 \\
(0.0946)\end{array}$ & $\begin{array}{c}0.0488 \\
(0.0868)\end{array}$ & $\begin{array}{l}0.0184 \\
(0.121)\end{array}$ & $\begin{array}{l}-0.0452 \\
(0.119)\end{array}$ & $\begin{array}{l}-0.0240 \\
(0.0833)\end{array}$ & $\begin{array}{c}0.0580 \\
(0.0911)\end{array}$ & $\begin{array}{l}-0.0646 \\
(0.0419)\end{array}$ & $\begin{array}{l}-0.0615 \\
(0.0475)\end{array}$ \\
\hline Bachelor's Degree & $\begin{array}{l}-0.0592 \\
(0.0424)\end{array}$ & $\begin{array}{l}-0.0771^{*} \\
(0.0437)\end{array}$ & $\begin{array}{l}-0.0152 \\
(0.0598)\end{array}$ & $\begin{array}{l}0.00911 \\
(0.0591)\end{array}$ & $\begin{array}{c}0.0428 \\
(0.0528)\end{array}$ & $\begin{array}{c}0.0356 \\
(0.0549)\end{array}$ & $\begin{array}{c}0.0316 \\
(0.0230)\end{array}$ & $\begin{array}{c}0.0323 \\
(0.0251)\end{array}$ & $\begin{array}{l}-0.111^{*} \\
(0.0638)\end{array}$ & $\begin{array}{l}-0.118^{* *} \\
(0.0550)\end{array}$ & $\begin{array}{c}-0.00346 \\
(0.0870)\end{array}$ & $\begin{array}{c}0.0361 \\
(0.0812)\end{array}$ & $\begin{array}{c}0.0158 \\
(0.0688)\end{array}$ & $\begin{array}{l}0.00459 \\
(0.0622)\end{array}$ & $\begin{array}{c}0.0990 * * \\
(0.0431)\end{array}$ & $\begin{array}{l}0.0771^{*} \\
(0.0443)\end{array}$ \\
\hline Good Health & $\begin{array}{c}-0.0734 \\
(0.0711)\end{array}$ & $\begin{array}{l}-0.0780 \\
(0.0699)\end{array}$ & $\begin{array}{c}-0.515^{* * *} \\
(0.116)\end{array}$ & $\begin{array}{c}-0.472 * * * \\
(0.108)\end{array}$ & $\begin{array}{c}-0.147 \\
(0.0972)\end{array}$ & $\begin{array}{c}-0.162^{*} \\
(0.0970)\end{array}$ & $\begin{array}{c}0.735 * * * \\
(0.145)\end{array}$ & $\begin{array}{c}0.712^{* * *} \\
(0.131)\end{array}$ & $\begin{array}{c}0.0424 \\
(0.0944)\end{array}$ & $\begin{array}{c}0.0354 \\
(0.0884)\end{array}$ & $\begin{array}{l}-0.227 \\
(0.156)\end{array}$ & $\begin{array}{l}-0.214 \\
(0.158)\end{array}$ & $\begin{array}{c}0.135 \\
(0.159)\end{array}$ & $\begin{array}{c}0.116 \\
(0.166)\end{array}$ & $\begin{array}{c}0.0499 \\
(0.0722)\end{array}$ & $\begin{array}{c}0.0630 \\
(0.0751)\end{array}$ \\
\hline Financial Literacy Score & $\begin{array}{c}-0.0151 \\
(0.00943)\end{array}$ & & $\begin{array}{c}0.0174 \\
(0.0158)\end{array}$ & & $\begin{array}{l}-0.0190 \\
(0.0145)\end{array}$ & & $\begin{array}{c}0.0166 \\
(0.0115)\end{array}$ & & $\begin{array}{l}0.00717 \\
(0.0168)\end{array}$ & & $\begin{array}{c}0.0181 \\
(0.0248)\end{array}$ & & $\begin{array}{l}-0.0337 \\
(0.0221)\end{array}$ & & $\begin{array}{l}0.00847 \\
(0.0149)\end{array}$ & \\
\hline Social Security Knowledge Score & $\begin{array}{c}-0.00724 \\
(0.0207)\end{array}$ & & $\begin{array}{l}-0.00826 \\
(0.0306)\end{array}$ & & $\begin{array}{c}0.0408 \\
(0.0293)\end{array}$ & & $\begin{array}{c}-0.0253^{*} \\
(0.0136)\end{array}$ & & $\begin{array}{c}-0.0277 \\
(0.0341)\end{array}$ & & $\begin{array}{c}0.0491 \\
(0.0555)\end{array}$ & & $\begin{array}{c}0.0118 \\
(0.0474)\end{array}$ & & $\begin{array}{l}-0.0332 \\
(0.0299)\end{array}$ & \\
\hline "Benefits Unaffected by Start Age" & & $\begin{array}{c}0.0646 \\
(0.0570)\end{array}$ & & $\begin{array}{l}-0.0321 \\
(0.115)\end{array}$ & & $\begin{array}{c}0.00357 \\
(0.119)\end{array}$ & & $\begin{array}{c}-0.0361 \\
(0.0593)\end{array}$ & & $\begin{array}{c}0.00308 \\
(0.129)\end{array}$ & & $\begin{array}{l}0.479 * * \\
(0.214)\end{array}$ & & $\begin{array}{c}0.542^{* * *} \\
(0.139)\end{array}$ & & $\begin{array}{c}-1.025^{* * *} \\
(0.208)\end{array}$ \\
\hline "Must Claim upon Retirement" & & $\begin{array}{l}-0.0778 \\
(0.112)\end{array}$ & & $\begin{array}{l}-0.0839 \\
(0.143)\end{array}$ & & $\begin{array}{l}0.0381 \\
(0.126)\end{array}$ & & $\begin{array}{c}0.124 \\
(0.0846)\end{array}$ & & $\begin{array}{l}0.0937 \\
(0.205)\end{array}$ & & $\begin{array}{l}-0.370 \\
(0.310)\end{array}$ & & $\begin{array}{c}0.181 \\
(0.146)\end{array}$ & & $\begin{array}{l}0.0955 \\
(0.121)\end{array}$ \\
\hline Observations & 403 & 403 & 403 & 403 & 403 & 403 & 403 & 403 & 183 & 183 & 183 & 183 & 183 & 183 & 183 & 183 \\
\hline
\end{tabular}

*** $p<0.01, * * p<0.05, * p<0.1$ 